\title{
Correction to: An integrated social life cycle assessment of freight transport systems
}

\author{
Jose Luis Osorio-Tejada ${ }^{1}$ (D) Eva Llera-Sastresa ${ }^{2} \cdot$ Sabina Scarpellini $^{3} \cdot$ Ahmad Hariza Hashim $^{4}$
}

Published online: 13 March 2020

(C) Springer-Verlag GmbH Germany, part of Springer Nature 2020

\section{Correction to: The International Journal of Life Cycle} Assessment

https://doi.org/10.1007/s11367-019-01692-w

The original version of this article unfortunately contained two mistakes. The spelling of Sabina Scarpellini's name was incorrect. In addition, the presentation of Table 6 was incorrect. The correct version of Table 6 is given below.

The original article has been corrected.

Table 6 Aggregation of valuations to variables in the 1 to 5 scale

\begin{tabular}{|c|c|c|}
\hline Original scale & & New scale \\
\hline Continuous & Discrete & Continuous Color \\
\hline $0.00-2.00$ & 1 & $1.00-1.80$ \\
\hline $2.00-4.00$ & 2 & $1.80-2.60$ \\
\hline $4.00-6.00$ & 3 & $2.60-3.40$ \\
\hline $6.00-8.00$ & 4 & $3.40-4.20$ \\
\hline $8.00-10.00$ & 5 & $4.20-5.00$ \\
\hline
\end{tabular}

The online version of the original article can be found at https://oi.org/ 10.1007/s11367-019-01692-w

Jose Luis Osorio-Tejada

jlosorio@utp.edu.co

1 Territorial Environmental Management Research Group -GAT-, Faculty of Environmental Sciences, Universidad Tecnológica de Pereira, Alamos, Pereira 660003, Colombia

2 Department of Mechanical Engineering, University of Zaragoza, Campus Rio Ebro, 50018 Zaragoza, Spain

3 Department of Accounting and Finance, University of Zaragoza, Paseo de la Gran Via, 2, 50005 Zaragoza, Spain

4 Faculty of Human Ecology, Universiti Putra Malaysia, 43400 Serdang, Selangor, Malaysia 